\title{
Learning Behind Bars: An Inquiry into the Early Development of Correctional Education in Oregon
}

Tashia Davis, Honors College

\begin{abstract}
In the timeline of criminal justice, integrating education into the prison system is a fairly recent development that did not emerge until the early 1900s. In Oregon in particular, we can track these changes through the progress made at the Oregon State Penitentiary. This paper asks when and to what extent did organized correctional education programs for male prisoners at the Oregon State Penitentiary develop prior to 1929 ? To answer this question, I compare the findings of the "father of correctional education," Austin H. MacCormick, to three main source bases: newspaper articles from the time period, a book on Oregon prison superintendents, and accounts of prisoners in the OSP inmate magazines Lend A Hand and Shadows. While MacCormick stated that there were no education programs in place when he visited the Oregon State Penitentiary in 1929, my other sources suggest otherwise.
\end{abstract}

Many criminologists recognize the year 1929 as the beginning of the modern trend in correctional education. ${ }^{1}$ It was around this time that societal sentiments about prisoners shifted from "once a crook, always a crook" toward a belief in the possibility of rehabilitation. ${ }^{2}$ However, it took years of deliberation to reach this change in thought and finally introduce education into America's prison systems. In Oregon in particular, the majority of these changes were first implemented into the Oregon State Penitentiary (OSP) in Salem: the state's oldest prison and its largest throughout the first half of the twentieth century. ${ }^{3}$

My research question asks: When and to what extent did organized correctional education programs for male prisoners at the Oregon State Penitentiary develop leading up to the year 1929? To answer this question I will compare the studies of the "father of correctional education,” Austin H. MacCormick, to three main source bases. I begin by analyzing several newspaper articles from the time period relating to prison education in Oregon. Next, I examine a book on Oregon prison superintendents by Sue Woodford-Beals and Carl E. Beals titled: Oregon State Prison Superintendents: The Shepherds of State Street 1864-2009. Finally, I explore accounts of prisoners in the OSP inmate magazines Lend A Hand and Shadows.4 I argue that MacCormick did not give the OSP enough credit in stating that no form of education existed at the prison when he visited on July 12, 1928. My sources indicate that academic programs were in place at the prison as early as 1912 and as close to his visit as 1926 and 1931.

The year 1929 is significant in modern correctional education due to MacCormick's service as the Assistant Director of the US Bureau of Prisons. His book, The Education of Adult 
Prisoners, published in 1931, presents his research from a grant through the National Society of Penal Information to study educational and library work in American prisons. Through 1927 and 1928, MacCormick visited all but three federal prisons in the country and made a "general survey" of their educational programs and libraries. The goal was to formulate "a program which may be adopted as a standard for penal institutions." 5 It is clear that his seminal work provided the foundation for studies and histories of correctional education in a number of forms since. MacCormick's opinion was the only one taken into consideration in every source that I found, including Marjorie J. Seashore and Steven Haberfeld's Prisoner Education: Project NewGate and Other programs, the American Prison Association's Correctional Education Today, the American Academy of Political and Social Science's Prisons of Tomorrow, and Lawrence D. Salmony's Corrections Education in Oregon: A Way to Proceed. ${ }^{6}$ In each account, his conclusions were neither supplemented by further studies nor his methods critically examined.

In The Education of Adult Prisoners, MacCormick makes the general conclusion, "Not a single complete and well-rounded educational program, adequately financed and staffed, was encountered in all the prisons in the country." Furthermore, he states, "There is no educational program in thirteen of these prisons," followed by a list that includes the OSP. He continues on to note the wide range of programs he found across the country:

In about an equal number [to those with no program] the educational work makes little more than a halting and grudging bow to state laws requiring that every prisoner...shall be given a third or fifth grade education. In less than a dozen prisons the work is extensive enough or effective enough or sufficiently well supervised to rise above the level of mediocrity. In the remainder, the educational work has little significance in spite of conscientious efforts of those in charge and the inmates who work under them.7

Although the scale of success MacCormick uses to judge education in prisons by is rather vague, he specifically discusses why the OSP made the short list in the Handbook of American Prisons and Reformatories. For each institution, MacCormick includes an analysis of the grounds, the administration, the prisoners themselves, discipline, health, industries, religion, inmate community organization, cost, and education. However, under the "education" section for the OSP, he writes a single sentence: "There is no educational work." Then, in his final comments on the OSP, MacCormick observes, "a fairly good library has been developed but this is one of the few institutions in the country of its size in which no educational work is done." 8 This stands out against the descriptions of education in other prisons, in which MacCormick acknowledges the existence of correspondence courses, the presence of a physical area devoted to school, state laws requiring education, and alternative methods of education such as periodically bringing in teachers or ordering textbooks for independent study.

In reading MacCormick, one is led to believe there was no education program of any kind at the OSP, or any efforts the state had made to provide education to its prisoners worth mentioning. MacCormick's high status in regard to the American prison system, his systematic study of every prison in the country, and the lack of a prominent contemporary in his field give him (previously) unquestioned credibility in the canon of correctional education literature. 
However, the following evidence indicates that not only did education programs exist at the OSP prior to MacCormick's visit, but they "sufficiently...rose above the level of mediocrity" marking the top dozen educational programs in the country leading up to and directly after 1928.

Newspaper articles can provide insight into the timeline of educational programs in place at the OSP. A 1902 article in The Daily Journal, a Portland newspaper, recounts a sermon given by Reverend Eliot in response to a recent prison riot. The reverend's sentiments toward prison reflect the strictly punitive view popular before widespread educational reform in the late twenties: "The jail, which is often nothing more than a country club house for the criminal class, is one of the causes of crime... Men are not punished out of justice to the criminal, but in justice to society." Regarding education, Reverend Eliot states, "Education alone is not a solution. A rogue by nature, a man's roguery is multiplied by education...Firstly education is not a cause of crime and secondly, it is not a cure for crime." 9 The prison was seen as a place for society to seek vengeance against its malcontents and deter them from future crime, not to educate and reform.

The reverend's sermon conflicts with the emerging belief in the reformation of the prisoner exemplified in a 1902 article in The Morning Oregonian, another Portland newspaper: "Aside from punishment by confinement in the Penitentiary, the enforcement of rigid discipline, and employment at useful labor, the other means of accomplishing the reform of the prisoners is through education." The article describes the library at the OSP and the calls by Superintendent Lee to employ an usher to "conduct a night school for those prisoners who desire to attend it." 10 An article in the same newspaper 20 years later entitled "Modern Prison Methods" states, "Prisoner though he be, society has not the right to break his body and spirit." 11 These instances illustrate that there was a conversation brewing about correctional education in Oregon as early as 1902.

After 1902, I was unable to find any concrete indication of developments in correctional education until a 1926 article in the Christian Science Monitor in Boston called "Prisoners Eager to Learn to Improve Life by Study." 12 It reads, "Inmates of the Oregon State Penitentiary who show signs of rehabilitation are receiving every encouragement by J. W. Lillie, warden, who has installed a correspondence course for their benefit." These courses allowed teachers and professors from surrounding schools and universities to provide inmates with education ranging from elementary subjects to more advanced college instruction to be completed during leisure time in the prisoners' cells. The article gave an optimistic rendition of these correspondence courses, which Oregon was "among the first on the Pacific coast" to introduce.

This would seem like a definitive example of education programs in place at the OSP prior to 1929. However, these efforts were not significant enough to have their own designated area on a Sanborn Fire Insurance map until corrections were made sometime between 1927 and 1951, when the main area behind the administration building reserved for the chapel and hospital turned into the library and school (See Figures 1 and 2). Even if the change was made with the first correction in 1927, there is still discrepancy in the exact introduction of correspondence courses into the OSP. A 1936 article in the Oregon Daily Emerald that describes the correspondence courses offered at the prison states, "During the last year the prisoners at Salem who wish to continue their education have been carrying on correspondence 
courses with the general extension division of the University."13 This would imply that the courses did not start until 1935, or that they had been suspended in 1926 and then restarted nine years later. It is difficult to disprove one newspaper account or the other, but nevertheless there is still evidence that the courses were in place and would qualify as an organized educational program that should have been acknowledged in MacCormick's study.

The compilation of OSP superintendents provides a more chronologically sound picture of education reform at the prison. The first superintendent, Major Montgomery P. Berry, "provided an area where school was taught by better educated fellow inmates" during his time in office from 1866 to 1870. After Berry, George S. Downing is said to have "recommended construction of a building to be used for hospital purposes, a portion of which could be for a reformatory school, "where young criminals could receive moral and religious training"' during his term from 1888-1895. It is unclear if he succeeded in starting the school, but the motive to do so is apparent. After this, no education programs were observed until Charles A. Murphy's term from 1916-1918, during which he devoted a corner of the inmate dining room to providing elementary education to inmates. Woodford-Beals writes, "The school area was outfitted with slates, text books and writing tablets. [Murphy] indicated that the foreign born inmates especially benefited from learning to read and write." However, the author adds, "Murphy's reform policies were short lived because of the occurrence of 58 escapes during the span of 1917 and 1918." The final mention of educational efforts of superintendents before 1929 is "humanitarian" Johnson S. Smith's "soft glove" approach to the handling of inmates in 1923. He believed that good health, skill, education, and attitude were critical to an inmate's success and attempted to mold public opinion into believing this, too. Woodford Beals did not describe any educational pursuits in particular, but she did say that, like Murphy, Smith's lenient policies were blamed for 37 escapes in his first and only six months as superintendent. ${ }^{14}$

The correspondence courses under Warden J. W. Lillie that were praised in the Christian Science Monitor were not mentioned in his biography in Oregon State Superintendents. However, Woodford-Beals states that correspondence courses were provided to all prisoners through the University of Oregon under Superintendent James W. Lewis during his term from 1931 to 1938. If the Christian Science Monitor was correct, this could mean that the unpopular Superintendent H. W. Meyers discontinued the correspondence courses put in place by Lillie and Lewis during his four-year term from 1927 to 1931. This would explain why MacCormick might have overlooked the existence of educational programs at the OSP when he visited in 1928.

In assessing the reliability of Oregon State Prison Superintendents, it is important to note the reason for its publication. Unlike the majority of my sources, this book is not the result of a study, nor is it a history or a report. The subtitle "Shepherds of State Street" and the biographical nature of the excerpts on each superintendent suggest that the motive behind the work seems to be more to praise and commemorate the efforts of the superintendents over the years. It is not clear what connection Woodford-Beals and Beals have to the OSP, and there are many grammatical and stylistic errors in the text, which indicate that their work may not have been heavily edited or checked for facts for scholarly use. Although citations and photos are included, the research was not methodical like that of MacCormick, so the authors could have 
excluded details about educational programs from some of the biographies prior to 1929. Nonetheless, the text gives evidence that efforts to provide education to inmates were in place as early as 1866, and that more organized programs were in place by Charles A. Murphy's term in 1916.

My third and perhaps most reliable source base are the monthly publications that were edited, contributed to, and printed by the inmates at the OSP. Lend A Hand was born in 1903 and continued until 1936, when it became Shadows. The mission of Lend A Hand was "to encourage moral and intellectual improvement among the inmates; to devote its energies along lines calculated to lead recreant ones back to usefulness in society; to acquaint the public with our true status, and to dispel the prejudice which exists against those who have paid the penalty of their transgressions." The magazines themselves represent the preexisting education of the prisoners and the desire to promote "intellectual improvement among the inmates," although this is certainly not reflective of the majority of the prison population. They also present an inside view of the prison that is untainted by outside sources. Even though the magazines do reflect the bias of the inmates, I have no reason to believe that their reports on prisoner education programs should be questioned for accuracy.

The earliest issue of Lend A Hand that I could obtain was from 1908. The first few years of the magazine did not yield precise evidence of education programs at the OSP, but they did include a number of articles suggesting that they were not far from being a reality. In an article called "Trade Schools the Convicts' Hope of Reform," author Johnnie "Reb." states, "Throughout the country, in almost every state, conditions have been made such that any person confined within a reformatory or penitentiary may attend a school of letters and receive competent instruction in a trade school." 15 He continues to highlight some of the institutions that participated in this, but he does not specifically say anything about Oregon. An unknown author of a 1909 article entitled "Kindness and Education Accomplish Reformation" praises the practices of the Indiana Reformatory and includes the trustees report from the prison in full that "shows for itself the beneficial results that are being obtained by kindness and education...The school of letters is upon an excellent basis and much good in the matter of education is being done for the illiterate and wayward men who come to the Institution."16 A poem in the same issue called "Does An Education Pay?" adds to the collection of pieces in the magazine in favor of education in prisons: "Does it pay for an acorn to become an oak? Does it pay to fit oneself for a superior position? Does it pay to get a glimpse of the joy of living? Does it pay to experience the joy of self-discovery, to open up whole continents of possibilities in one's nature which might otherwise remain undiscovered?-Success." 17 In several additional cases, the inmates printed articles praising the education programs in place at other institutions and speaking to what their idea of modern penology should be in order to benefit both the prisoner and society.

There is no mention of education at the OSP until a March 1912 article entitled "Schools in Prison Tend to Reformation." An unspecified author writes, "the OSP, along with many other prisons, has instituted a school for the inmates, in which the practical elementary branches are taught." The writer adds, "Among the prisons in this institution are some highly educated men, some of them experienced teachers. In addition, a number of teachers from the schools and colleges of Salem have kindly volunteered their services. On the whole, the classes are now well 
supplied with competent instructors." He points out that schools in prisons may even be more beneficial to students on the inside than on the outside because there are no distractions and students have ample time and regular hours. Furthermore, visitors were impressed with the "earnestness and enthusiasm" of the incarcerated students. ${ }^{18}$ Although the article does not provide more details about the education program such as how many students were enrolled and how often classes took place, it provides convincing evidence that an organized education program was in place at the OSP as early as 1912.

After this article, proof of education programs at the OSP was not hard to find. A second article in the March 1912 issue called "Ambition Among Prisoners" describes the more than 30 men studying Spanish at a night school at the prison, along with a "much larger number" of inmates taking classes in math and English. ${ }^{19}$ The writer of the article even mentions that he teaches a class at the school at the prison. A November 1912 passage advertises a Shakespeare class held every Wednesday evening in the penitentiary auditorium with a membership of 24 incarcerated students. The excerpt reads that the class was developed "more than three and a half years ago," which would have been in 1908, but I found no mention of the class until the 1912 issue. A feature of the course was the opportunity for each student to learn "extemporaneous speaking" in front of the class. ${ }^{20}$ The remaining volumes of Lend A Hand were unavailable except for volumes 16 and 17 from the years 1921 to 1922 . These issues continued the discussion about education in prisons but did not contain concrete evidence of an education program at the OSP.

Developments in correctional education as a whole in the United States spread in the 1930s, receded, and then came back in favor in the 1960s. ${ }^{21}$ The situation at the Oregon State Penitentiary is no exception. In taking all three source bases into consideration, there were discrepancies in the timeline and the degree of success of education programs at the OSP. However it is apparent that the programs existed before and after 1929, regardless of their results. Not only were they present, but they also seem to have evolved into programs that should have been mentioned by the figure who spearheaded the correctional education movement, Austin H. MacCormick. There is no easy way to decipher the reason why MacCormick did not find any educational developments worth mentioning at the OSP. My best guess would be that either the programs phased out during his visit in 1928, or that his research of the prison was not thorough enough. After comparing MacCormick's work to the newspapers, superintendent biographies, and inmate magazines, it is evident that the question of when and how correctional education developed at the OSP was not as clear-cut as expected.

\section{ACKNOWLEDGEMENTS}

I'd like to thank Shaul Cohen and Phoebe Petersen for facilitating an enlightening class through the Inside Out Program at the Oregon State Penitentiary. I would also like to thank Ocean Howell for truly challenging me and for making me a better writer. Finally, I'd like to thank my parents for being the best mentors I could ever ask for.

\section{REFERENCES}


“Ambition Among Prisoners,” Lend A Hand, (Salem: Oregon State Penitentiary), v. 8.

"Civil Works Service Projects in Education: Correspondence Courses," Oregon State System of Higher Education Leaflet Series, (Salem: State Board of Higher Education, 1932).

Coley, Richard J. and Paul E. Barton, Locked Up and Locked Out: An Educational Perspective on the U.S. Prison Population, (Princeton, NJ: Policy Evaluation and Research Center, 2006).

Correctional Education Association, "Correctional Education LINCS Special Collection," NW LINCS: Home Page. Accessed April 27, 2013. http://www.nwlincs.org/correctional_education/history.html

Crayton, Anna and Suzanne Rebecca Neusteter, "The Current State of Correctional Education," John Jay College of Criminal Justice. Accessed April 27, 2013. www.jjay.cuny.edu/craytonneusteter_finalpaper.pdf

Doan, Mike, "OSU Professors Aid Prison College," The Oregonian, June 2, 1967, 21.

“Does An Education Pay?” Lend A Hand, (Salem: Oregon State Penitentiary), v. 5.

"Educating the Women Prisoners," Daily Capital Journal, April 4, 1910, Historic Oregon Newspapers, Web, accessed April 27, 2013.

Garrett, Paul W. and Austin H. MacCormick. "Oregon State Penitentiary, Salem, Oregon," In the Handbook of American Prisons and Reformatories, (New York, N.Y.: National Society of Penal Information, 1929), 797-806.

Gehring, Thom, "Post-Secondary Education for Inmates: An Historical Inquiry," Journal of Correctional Education, 48(2), 1997, 46-55.

"Good report made on Oregon prison," The Sunday Oregonian, August 10, 1930, 9.

Guernsey, John, "Rep. Green Asks Financial Investigation of 2 Upward Bound Programs," The Oregonian, July 27, 1968, 9.

Jaquiss, Nigel, "The Hard Truth About Oregon's Prisons: They Work," The Willamette Week, March 13, 2013. Accessed April 28, 2013. http://www.wweek.com/portland/article20373the_hard_truth_about.html

Johnnie “Reb.," “Trade Schools the Convicts' Hope of Reform,” Lend A Hand, (Salem: Oregon State Penitentiary), v. 4.

“Kindness and Education Accomplish Reformation," Lend A Hand, (Salem: Oregon State Penitentiary), v. 5. 
MacCormick, Austin H, Handbook of American Prisons and Reformatories; Vol. II: Pacific coast states, $5^{\text {th }}$ ed, (New York: Osborne Association, 1942).

MacCormick, Austin H. The Aducation of Adult Prisoners: A Survey and a Program, (New York: National Society of Penal Information, 1931).

Mason, Robert George and Alexander Seidler, Effects of prison vocational training and education programs on employment success and recidivism, (Corvallis, OR: Survey Reasearch Center, Oregon State University, 1977).

"Modern Prison Methods," The Morning Oregonian, September 29, 1923, 10.

Murton, Thomas O., The Dilemma of Prison Reform, (New York: Holt, Rinehart and Winston, 1976), print.

"Prison Called Old-Fashioned," The Oregonian, October 15, 1942, 8.

"Prisoners Eager to Learn to Improve Life by Study," The Christian Science Monitor, November 8, 1926, 1.

"Prison labor plan: industrial play proposed for Oregon State Prison," The Morning Oregonian, September 9, 1924, 8.

Rasmussen, Marie, "Inmates of State Prison Publish Monthly Magazine," Oregon Daily Emerald, January 31, 1936, 1, 4.

Reagen, Michael V. and Donald M. Stoughton, School Behind Bars: a descriptive overview of correctional education in the American prison system, (Metuchen, N.J.: The Scarecrow Press, 1976).

"Replies to Labor," The Morning Oregonian, August 28, 1902, 10. Accessed April 27, 2013. http://oregonnews.uoregon.edu/

"Reverend Elliot on Jails," The Daily Journal, June 23, 1902. Accessed April 27, 2013. http://oregonnews.uoregon.edu/

Roberts, Albert R., Sourcebook on Prison Education: Past, Present, and Future, (Springfield, Ill: Thomas, 1971).

Rondema, Jessica, "Oregon State Penitentiary," Oregon Encyclopedia: Oregon History and Culture. Accessed April 28, 2013. http://www.oregonencyclopedia.org/entry/view/ oregon_state_penitentiary/

Salmony, Lawrence D., Corrections Education in Oregon: A Way to Proceed (Salem: State of 
Oregon, Educational Coordinating Council, 1974).

"Schools in Prison Tend to Reformation," Lend A Hand, (Salem: Oregon State Penitentiary), v. 8.

Seashore, Marjorie J. and Steven Haberfeld, Prisoner Education: Project Newgate and other college programs, (New York: Praeger, 1976).

Shadows, (Salem: Oregon State Penitentiary, 1936).

“Shakespeare Class,” Lend A Hand, (Salem: Oregon State Penitentiary), v. 8.

Smith, Mark K., "Alexander Paterson, youth work and prison reform," Infed. Accessed April 28, 2013. http://infed.org/mobi/alexander-paterson-youth-work-and-prison-reform/

Smith, Robert A., "Edith Green Charges Conflict of Interest In Oregon State Prison Upward Bound Program," The Oregonian, December 12, 1969, 45.

Snedden, David, Administration and Educational Work of American Juvenile Reform Schools, (New York: Teachers College, Columbia University, 1907). Print.

Sutherland, Edwin H. and Thorsten Sellin, eds., Prisons of Tomorrow, (Philadelphia: American Academy of Political and Social Science, 1931).

Thimm, Joseph L. and Gerald Jacobson, An Evaluation of the Upward Bound Oregon Prison Project, (Salem: Corrections Division, Oregon State Board of Control, 1968).

"Torture No Deterrent," The Ontario Argus, June 17, 1915, 2. Accessed April 27, 2013. http://oregonnews.uoregon.edu/

"Uruguay," Medford Mail Tribune, November 11, 1915, 4. Historic Oregon Newspapers, Web, accessed April 27, 2013.

Wallack, Walter Marle, Correctional Education Today: first yearbook of the Committee on Education of the American Prison Association, (New York: American Prison Association, 1939).

Woodford-Beals, Sue and Carl E. Beals, Oregon State Prison Superintendents: The Shepherds of State Street 1864-2009, (Salem: Airy Woods Publishing Company, 2009). 


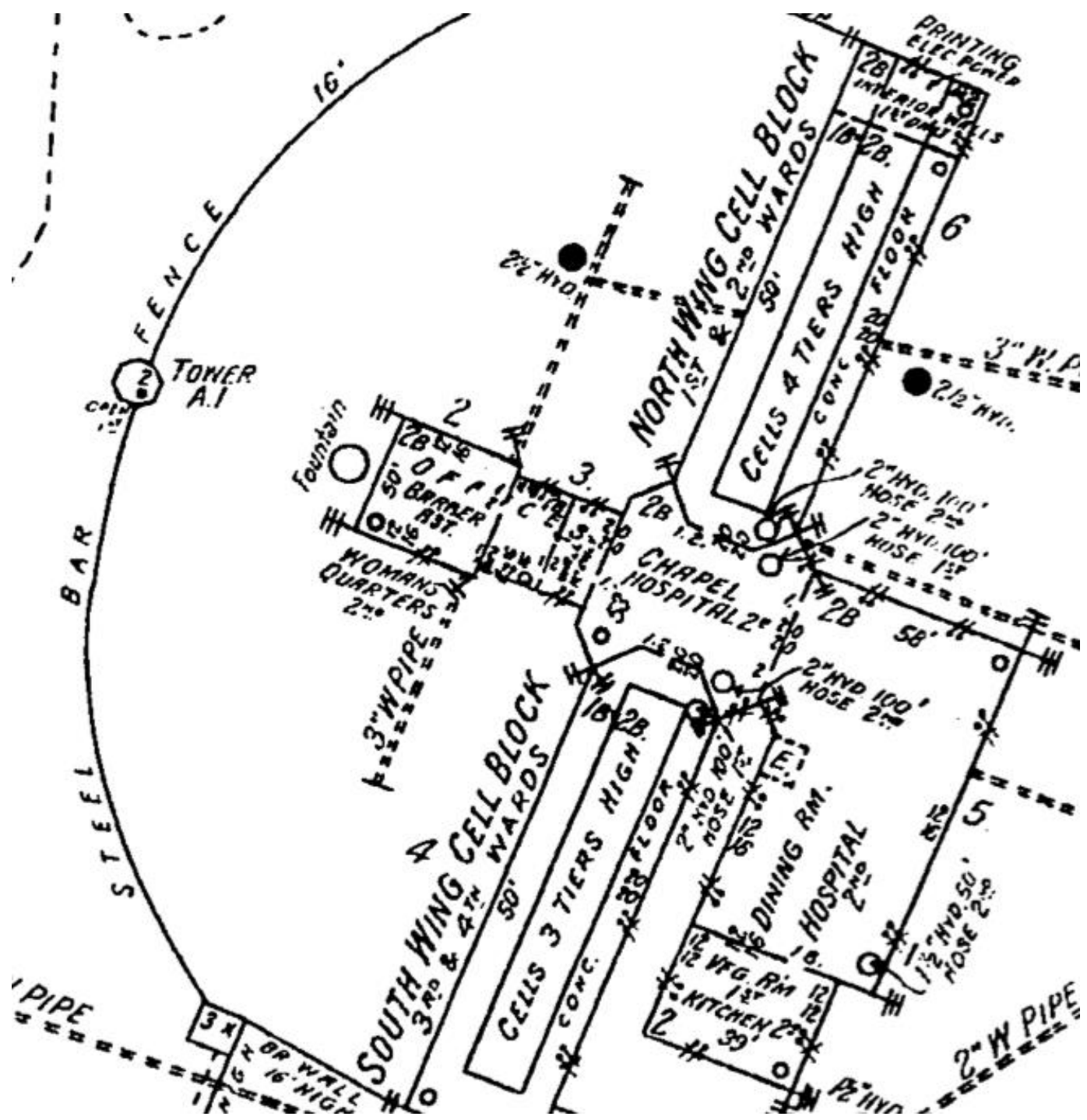

Figure 1: Salem, Oregon. 1926. 100 feet to one inch. "Sanborn Fire Insurance Maps, 1867-1970 Oregon.” Accessed June 6, 2013. http://sanborn.umi.com.libproxy.uoregon.edu/image/view?

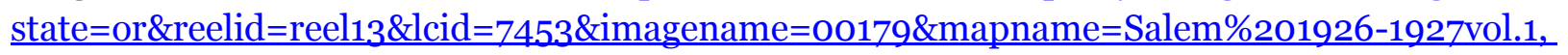
1926,\%20Sheet\%20182 


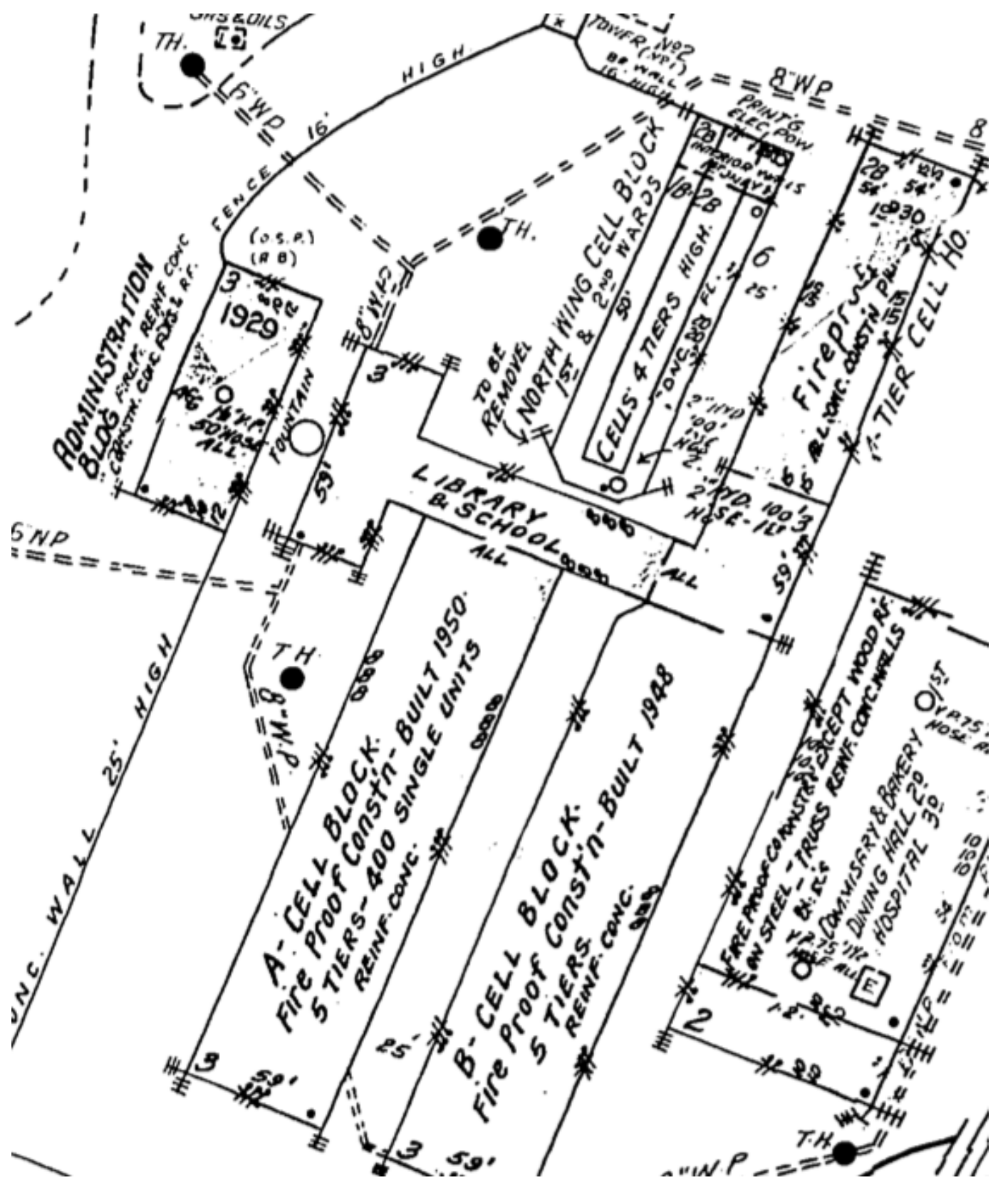

Figure 2. Salem, Oregon. 1927-1950. 100 feet to one inch. "Sanborn Fire Insurance Maps, 18671970 - Oregon.” Accessed June 6, 2013. http://sanborn.umi.com.libproxy.uoregon.edu/ $\underline{\text { sanborn } / \text { image } / \text { view } \text { state }=\text { or\&reelid }=\text { reel14\&lcid }=7453 \text { \&imagename }=00089 \text { \&mapname }=\text { Sale }}$

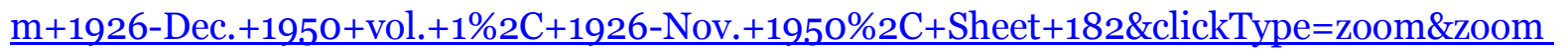
Name $=$ fit-window\&zoomValue $=0.290724718578472 \& C C S I=2197 n \&$ centerX $=161 \&$ centerY $=$ 188\&viewportWidth $=925 \&$ viewportHeight $=700$ 
NOTES

${ }^{1}$ Albert Roberts, Sourcebook on Prison Education: Past, Present, and Future (Springfield, Ill.: Thomas, 1971$), 9$.

${ }^{2}$ Lawrence D. Salmony, Corrections Education in Oregon: A Way to Proceed (Salem: State of Oregon, Educational Coordinating Council, 1974), 8.

3 Jessica Rondema, "Oregon State Penitentiary." Oregon Encyclopedia: Oregon History and Culture. Accessed April 28, 2013. http://www.oregonencyclopedia.org/entry/view/oregon_state_penitentiary/

4 Sue Woodford-Beals and Carl E. Beals, Oregon State Prison Superintendents: The Shepherds of State Street 18642009, (Salem: Airy Woods Publishing Company, 2009); Lend A Hand, (Salem: Oregon State Penitentiary), v. 4-8, 1718; Shadows, (Salem: Oregon State Penitentiary, 1936).

5 Austin H. MacCormick, The Education of Adult Prisoners: A Survey and a Program (New York: National Society of Penal Information, 1931), ix, 38.

${ }^{6}$ Marjorie J. Seashore and Steven Haberfeld, Prisoner Education: Project NewGate and Other College Programs (New York: Praeger, 1976), 17; Walter Marle Wallack, Correctional Education Today: First Yearbook of the Committee on Education of the American Prison Association (New York: American Prison Association, 1939), 17-32; Edwin H. Sutherland and Thorsten Sellin, eds., Prisons of Tomorrow, (Philadelphia: American Academy of Political and Social Science, 1931), 72-77; Salmony, 11.

7 MacCormick, 1931, 38-39.

8 Paul W. Garrett and Austin H. MacCormick, "Oregon State Penitentiary, Salem, Oregon," in the Handbook of American prisons and reformatories (New York, N.Y.: National Society of Penal Information, 1929). 797-806.

9 "Reverend Elliot on Jails," The Daily Journal, June 23, 1902. Accessed April 27, 2013.

http://oregonnews.uoregon.edu/

10 "Replies to Labor," The Morning Oregonian, August 28, 1902, 10. Accessed April 27, 2013. http://oregonnews. uoregon.edu/

11 "Modern Prison Methods," The Morning Oregonian, September 29, 1923, 10.

12 "Prisoners Eager to Learn to Improve Life by Study," The Christian Science Monitor, November 8, $1926,1$.

13 Rasmussen, Marie, "Inmates of State Prison Publish Monthly Magazine," Oregon Daily Emerald, January 31, 1936, 1,4 .

14 Woodford-Beals, Sue, and Carl E. Beals, Oregon State Prison Superintendents: The Sheperds of the Street 18642009, (Salem:Airy Woods Publishing Company, 2009).

15 Johnnie “Reb.," “Trade Schools the Convicts' Hope of Reform,” Lend A Hand, (Salem: Oregon State Penitentiary, 1908), v. 4.

16 "Kindness and Education Accomplish Reformation," Lend A Hand, (Salem: Oregon State Penitentiary, 1909), v. 5 .

17 “Does An Education Pay?” Lend A Hand, (Salem: Oregon State Penitentiary: 1909), v. 5.

18 "Schools in Prison Tend to Reformation," Lend A Hand, (Salem: Oregon State Penitentiary, 1912), v. 8.

19 “Ambition Among Prisoners,” Lend A Hand, (Salem: Oregon State Penitentiary, 1912), v. 8.

20 “Shakespeare Class," Lend A Hand, (Salem: Oregon State Penitentiary, 1912), v. 8.

${ }^{21}$ Richard J. Coley and Paul E. Barton, Locked Up and Locked Out: An Educational Perspective on the U.S. Prison Population, (Princeton, NJ: Policy Evaluation and Research Center, 2006). 